\title{
Waste paper for recycling: Overview and identification of potentially critical substances
}

\author{
Pivnenko, Kostyantyn; Eriksson, Eva; Astrup, Thomas Fruergaard
}

Published in:

Waste Management

Link to article, DOI:

10.1016/j.wasman.2015.02.028

Publication date:

2015

Document Version

Peer reviewed version

Link back to DTU Orbit

Citation (APA):

Pivnenko, K., Eriksson, E., \& Astrup, T. F. (2015). Waste paper for recycling: Overview and identification of potentially critical substances. Waste Management, 45, 134-142. https://doi.org/10.1016/j.wasman.2015.02.028

\section{General rights}

Copyright and moral rights for the publications made accessible in the public portal are retained by the authors and/or other copyright owners and it is a condition of accessing publications that users recognise and abide by the legal requirements associated with these rights.

- Users may download and print one copy of any publication from the public portal for the purpose of private study or research.

- You may not further distribute the material or use it for any profit-making activity or commercial gain

- You may freely distribute the URL identifying the publication in the public portal 
1 Waste Paper for Recycling: Overview and Identification of Potentially

\section{Critical Substances}

3

4

5

Kostyantyn Pivnenko $^{\mathrm{a}^{*}}$, Eva Eriksson ${ }^{\mathrm{a}}$, Thomas. F. Astrup ${ }^{\mathrm{a}}$

6

7

${ }^{a}$ Department of Environmental Engineering, Technical University of Denmark, Miljøvej Building 8 113, DK-2800 Kgs. Lyngby, Denmark

9

10

11

12

13

*) Corresponding author: Kostyantyn Pivnenko

14 Department of Environmental Engineering, Technical University of Denmark, Miljøvej Building

15 113, DK-2800 Kgs. Lyngby, Denmark

16 pivnenko.k@gmail.com

17 tlf: +454525 1602, fax: +4545932850

18 


\section{Abstract}

20 Paper product manufacturing involves a variety of chemicals used either directly in paper and pulp

21 production or in the conversion processes (i.e. printing, gluing) that follow. Due to economic and 22 environmental initiatives, paper recycling rates continue to rise. In Europe, recycling has increased 23 by nearly $20 \%$ within the last decade or so, reaching a level of almost $72 \%$ in 2012 . With increasing 24 recycling rates, lower quality paper fractions may be included. This may potentially lead to 25 accumulation or un-intended spreading of chemical substances contained in paper, e.g. by 26 introducing chemicals contained in waste paper into the recycling loop. This study provides an 27 overview of chemicals potentially present in paper and applies a sequential hazard screening 28 procedure based on the intrinsic hazard, physical-chemical and biodegradability characteristics of 29 the substances. Based on the results, 51 substances were identified as potentially critical (selected 30 mineral oils, phthalates, phenols, parabens, as well as other groups of chemicals) in relation to paper 31 recycling. It is recommended that these substances receive more attention in waste paper. 


\section{Abbreviations}

36 BBP: Benzyl butyl phthalate

37 BPA: Bisphenol A

38 CAS: Chemical Abstracts Service

39 CEPI: Confederation of European Paper Industries

40 DBP: Dibutyl phthalate

41 DEHP: Diethylhexyl phthalate

42 DIBP: Diisobutyl phthalate

43 DIPN: Diisopropyl naphthalene

44 EDCs: Endocrine Disrupting Chemicals

45 EFSA: European Food Safety Authority

46 EuPIA: European Printing Ink Association

47 FDHA: Swiss Federal Department of Home Affairs

48 NIAS: Non-Intentionally Added Substances

49 PCBs: Polychlorinated biphenyls

50 PBT: Persistent, Bioaccumulative and Toxic

51 vPvB: very Persistent and very Bioaccumulative

52 ZELLCHEMING: Vereins der Zellstoff- und Papier-Chemiker und -ingenieure (German for:

53 Association of Chemical Pulp and Paper Chemists and Engineers). 


\section{Introduction}

Paper recycling is one of the most well-established recycling schemes applied to waste materials today. Recycled paper is an integral part of paper and pulp production, with estimated utilisation for recycling in Europe of about 72\% in 2012 (an increase of 20\% from 2000) (CEPI, 2013a). In addition to recycled paper being an important raw material for the paper industry (CEPI, 2013b), it has also been demonstrated in several studies that paper recycling may offer significant environmental benefits in a lifecycle perspective (Laurijssen et al., 2010; Villanueva and Wenzel, 2007). Thus, paper recycling may be regarded as beneficial from both a resource and an environmental perspective and should be promoted as much as possible. However, increasing concerns related to the presence of potential harmful chemical substances in paper have been voiced within recent years (e.g. Biedermann et al., 2011b; Liao and Kannan, 2011; Pivnenko et al., 2013), for example in relation to the migration of chemicals from packaging materials into food (e.g. Begley et al., 2008; Biedermann et al., 2013; Gärtner et al., 2009; Lorenzini et al., 2013). While further increasing paper recycling rates can undoubtedly be achieved in Europe, the quality of the waste paper may ultimately decrease as more and more "marginal" paper fractions are collected for recycling and the contents of harmful substances in paper thereby increase. A systematic overview of the chemical substances potentially present in waste paper for recycling is therefore needed to provide a basis for further evaluation of the quality of waste paper as a resource, and ultimately also to maintain consumer acceptance of recycled paper in general.

Paper production and manufacturing operations generally consist of the following two phases: i) paper and pulp production by the paper industry (i.e. different quality grades of paper) and ii) paper product manufacturing by separate industries (e.g. periodicals, packaging materials, books, etc.). Chemicals in waste paper may originate from a wide range of sources, namely intentionally added (i.e. additives, inks, pigments, glues, etc.), part of a reaction and/or biodegradation or added 
during the use phase of the paper or during the waste management phase (e.g. cross-contamination from other waste materials during collection). Chemicals are added in order to improve the production process itself and the quality or functionality of the final product. Starting with paper production, chemicals are introduced through the use of synthetic additives, which include retention aids, sizing agents, coatings, biocides, synthetic binders, etc. Synthetic additives represent slightly more than $1 \% \mathrm{v} / \mathrm{v}$ of raw materials used in paper production (ZELLCHEMING, 2008), the largest share of which $(90 \% \mathrm{v} / \mathrm{v})$ are functional additives (Moench and Auhorn, 2002) intended to be retained in the paper product. The next step, where the paper is converted into a final product, may include printing, dyeing, addition of adhesives and labels, etc. During the processing, chemicals may dissolve and be removed via wastewater, volatilize and be released to air or remain in the solid matrix and thereby be present in newly manufactured paper products. When waste paper is added to the process, this may potentially introduce new substances from the use and waste management phase. Knowing which potential partitioning a given chemical (or group of chemicals) will follow is vital for identifying potentially critical substances which may end up being concentrated in the fibres and be reintroduced into consumer products.

Recent studies have demonstrated that paper and paper products may contain high numbers of chemical substances (BMELV, 2012; Bradley et al., 2008), most of which can be associated with the printing industry, where more than 7,000 chemicals may be used in food-packaging ink production alone (EuPIA, 2012).Nevertheless, very little quantitative information is available regarding the presence of specific substances in paper products or waste paper potentially sent to recycling. Most existing studies target a specific group of chemicals or paper products (e.g. Becerra and Odermatt, 2012; Geens et al., 2012; Song et al., 2000; Trier et al., 2011), and attempting to identify every single chemical present in paper has proved to be challenging (BMELV, 2012). 
Although specific regulations covering paper food packaging do not exist, European legislation on items (i.e. plastics, metal, paper, etc.) brought into contact with food prevents the use of chemicals that could migrate into foodstuffs and adversely affect human health, as well as the quality and nature of food (EC, 2004). This legislation covers paper packaging produced from virgin fibres, but when paper is recycled, the producers may not be aware of the presence of any specific chemicals added throughout the lifecycle of the paper. Consequently, the paper industry, and the final output paper quality, is affected by the presence of chemicals in the recycled paper, e.g. chemicals introduced during the use phase or via paper products from other countries. In 2012, more than 5 million tonnes of paper (approx.11\% of recycled paper) was imported into Europe from the USA, Russia, Brazil, Canada, etc. for paper product manufacturing (CEPI, 2013a).

Without a comprehensive overview of which chemical substances should be prioritised in relation to paper, and which substances should ultimately be avoided, it may not be possible in the future to ensure both high recycling rates and at the same time a high quality of the paper products based on recycled fibres. As direct and substance-by-substance analysis is not practically feasible, a systematic screening of un-problematic chemicals is needed, in order to identify those substances which may be considered most problematic and critical for the future recycling of paper.

The overall goal of this study is to provide a basis for systematically addressing the recyclability of waste paper with respect to the potential presence of hazardous substances. The specific objectives are: i) based on existing literature, to compile a list of chemical substances potentially applied in paper production and paper product manufacturing, as well as chemicals identified directly in paper, ii) based on a sequential hazard screening procedure to identify the most critical chemicals from this list based on their harmfulness, physical-chemical properties and biodegradability and iii) to evaluate potential implications related to the management of paper waste and paper recycling. 


\subsection{Data sources for chemicals in paper}

Information about chemical substances, used in either paper production or paper conversion, as well as chemicals identified in actual paper product flows, was obtained from a range of data sources.

130 Chemicals used in pulp and paper production were obtained from national product registries 131 (KEMI, 2014; SPIN, 2013) and scientific assessments (Riskcycle, 2013; ZELLCHEMING, 2008), as well as inventory data provided by the European Food Safety Authority (EFSA) (EFSA, 2012a). Substances used by the printing industry were obtained from a recent Danish report (Miljøstyrelsen, 2011a), an inventory list of the European Printing Ink Association (EuPIA) (EuPIA, 2012) and recent regulation issued by the Swiss Federal Department of Home Affairs (FDHA) (FDHA, 2005). Although data obtained for paper printing could not be isolated from the printing of other materials, the European printing industry belongs to a forest-based industrial sector, and the share of paper in the printing industry is substantial. All of the abovementioned data sources predominantly reflected European industry and research; this was not due to any selection of sources, but rather reflected availability of state-of-the-art information and level of detail provided. No information could be found related specifically to chemicals used in adhesives, so these were therefore only indirectly included in the study as part of the analytical literature reviewed. Additionally, relevant scientific literature addressing the composition of paper, paper products or waste paper was reviewed. While the aim was not to provide an exhaustive review of all available literature, the focus was placed on recent literature in order to relate any findings as best as possible to the current technological scope of the paper industry. No geographical scope was applied to the selected studies, as paper is a commodity traded on the global market with high volumes of paper, paper packaging and waste paper being imported and exported on a yearly basis. In total, 25 scientific studies were reviewed. 
149 Where available the concentrations of substances mentioned in the literature are also provided. See 150 Table 1 for a complete list of the data sources used in this paper.

Based on the abovementioned combination of information sources, a compilation of almost 10,000 chemical substances was obtained once duplicates were removed. To avoid ambiguity and 153 potential double-counting, only chemicals (or groups of chemicals) which could be assigned a valid 154 CAS (Chemicals Abstracts Service) registry number were included in the study.

155

\subsection{Criteria for identifying potential priority chemicals}

With the aim of identifying potentially critical chemicals that should be prioritised in relation to paper recycling, a screening selection procedure was applied for those that may be considered most harmful, most likely to be associated with paper fibres (and not volatilise or be released into the water phase during re-pulping) and the most persistent in the environment. The procedure involved the following four steps: 1) compiling an inventory of chemicals that may be used in the paper and printing industries or which may have been identified in paper (corresponding to the list of about 10,000 substances mentioned above), 2) identifying potentially harmful chemicals, 3) identifying chemicals primarily associated with solids (i.e. paper fibres) and 4) identifying chemicals characterised as not readily biodegradable. Steps 1) through 4) were carried out consecutively, thereby filtering out less problematic substances in relation to paper recycling. The remaining list of chemicals therefore represented substances that should be prioritised in future scenarios characterising paper and addressing paper recycling. See Figure 1 for an illustration of the procedure. 


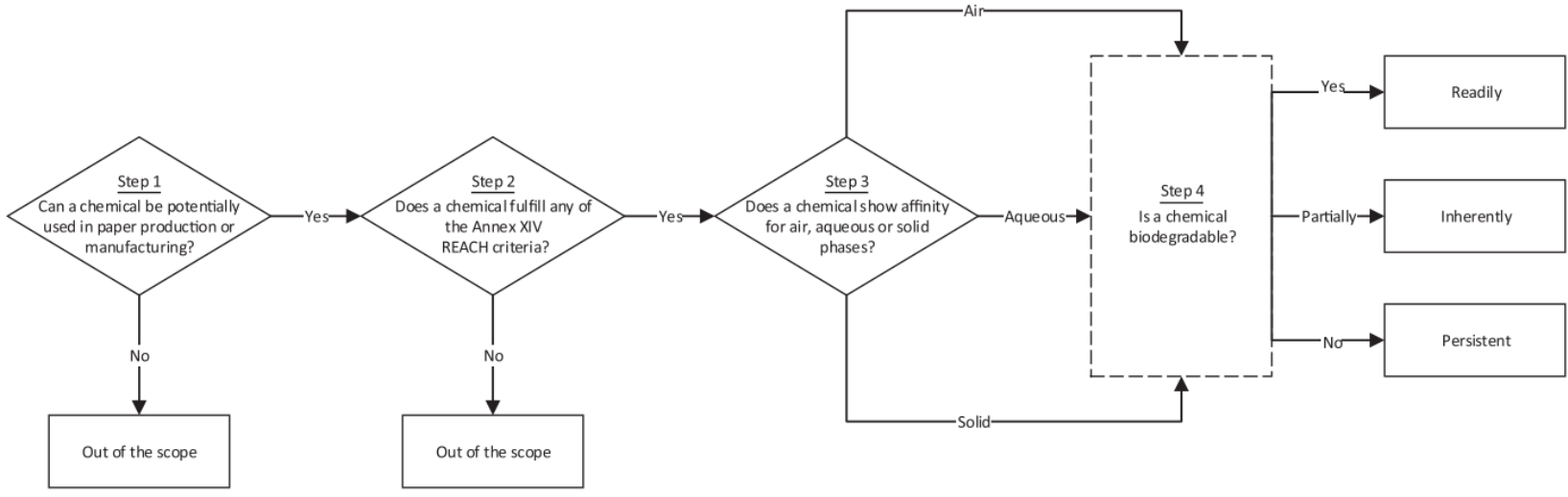

Figure 1. Schematic representation of the methodology applied in selecting relevant chemicals of 171 interest.

In Step 2), chemicals were selected in accordance with Annex XIV of European REACH Regulation (EC, 2006) and according to the following criteria: i) substances classified in hazard class “carcinogenicity” (categories 1A and 1B, Carc. 1A or 1B) (EC, 2008), ii) substances classified in hazard class "germ cell mutagenicity" (categories 1A and 1B, Muta. 1A or 1B) (EC, 2008), iii) substances classified in hazard class "reproductive toxicity” (categories 1A and 1B, Repr. 1A or 1B) (EC, 2008), iv) substances classified as "Persistent, Bioaccumulative and Toxic (PBT)” (according to Annex III in (EC, 2006)), v) substances classified as “very Persistent and very Bioaccumulative (vPvB)" (according to Annex III in (EC, 2006)) and vi) substances characterised as "Endocrine Disrupting Chemicals (EDCs)” (WHO, 2002) for which scientific evidence of possible serious 181 effects on human health and/or the environment could be found. The chemicals selected based on 182 Step 2 included all substances fulfilling at least one of the abovementioned criteria. Only substances with sufficient information available were selected in Step 2; in other words, those with nonpublished or incomplete hazard assessments were not included. In practice this means that the number of chemicals finally selected in this study might be underestimated, as future hazard 
assessments of chemicals included in inventory list (Step 1) may reveal additional substances fulfilling the Step 2 criteria.

Step 3) was based on the methodology described by Baun et al. (Baun et al., 2006), where partitioning between phases is based on the potential of a given chemical to be adsorbed to solids, to volatilise or to remain dissolved in the aqueous phase. Influence of particular paper production processes (pulping, coating, drying, etc.) on phase distribution of substances is out of the scope of the present work and was not considered.

In Step 4) of the screening process, chemicals were assessed in accordance with their biodegradability and then classified into persistent, inherently and readily biodegradable. Classification was based either on the Biowin models 3 and 5, included in EpiSuite 4.1 (U.S. EPA, 2013) with cut-off values as presented by Baun et al. (Baun et al., 2006), or on scientific literature providing experimental biodegradation results. Relevance of biodegradability of chemicals to particular processes in paper recycling was not established, as the variations associated with different steps of the paper lifecycle (i.e. paper production, manufacturing, use, waste paper collection, re-processing, etc.) are potentially large.

\section{Results and Discussion}

\subsection{Overview of substances}

Figure 2 presents material flows of European paper recycling, indicating points where chemicals are introduced into the loop. Most non-fibrous materials are introduced in the paper production step, but they are almost entirely represented by non-hazardous naturally occurring substances such as clay, $\mathrm{CaCO}_{3}$ and starch. No quantitative data were available regarding chemicals added non-intentionally into the loop (i.e. Non-Intentionally Added Substances, NIAS). An overview of each of the sources contributing to the final list in Step 1 is presented in Table 1. Although the paper industry uses high 

associated with paper products derives from printing (Table 1).

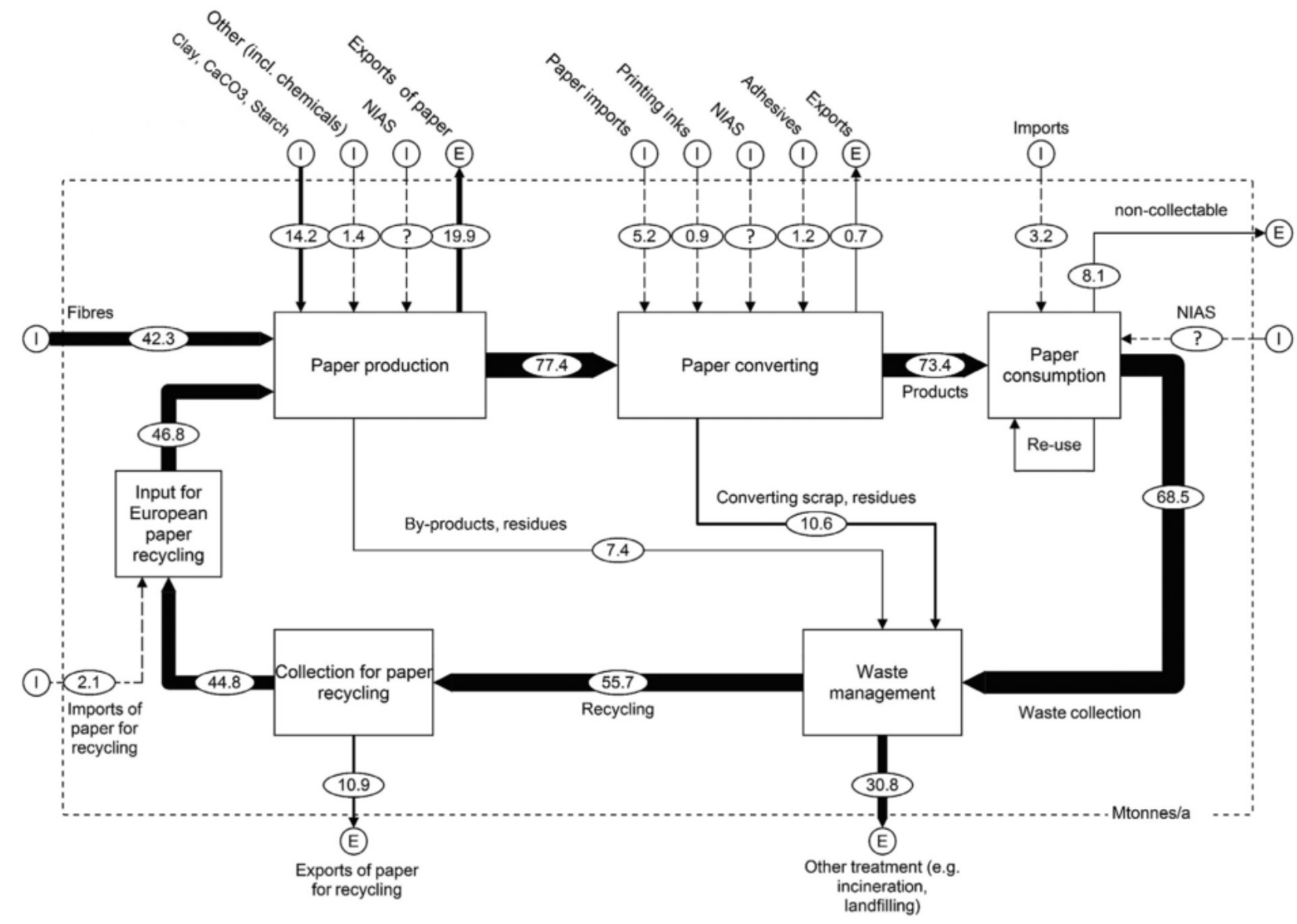

212 Figure 2. Material flow of the European paper recycling loop. Dotted lines indicate points where 213 chemicals are introduced (Based on (CEPI, 2013a, 2013b; EUPIA, 2013; FEICA, 2008.; ITC, 2014) 214 and personal communication with the Confederation of European Paper Industries (CEPI)). Due to the large number of chemicals identified in Step 1, attributing to each of them a potential use by industry is practically impossible. Nevertheless, most of the substances used in 217 paper production can be attributed to fillers, binders, retention aids, wet/dry-strength agents, 218 coaters, biocides, dispersers, etc. (ZELLCHEMING, 2008). In the printing industry the vast majority of chemicals are used as solvents, dyes, inks, pigments, binders, curing agents and photo- 
220 initiators, plasticisers, surfactants, etc. (Miljøstyrelsen, 2011a) Only a small fraction (157) of the 221 almost 10,000 substances could be identified in Step 2. Figure 3a presents the distribution of 222 substances on Step 2 list in accordance with their use by industries throughout the lifecycle of 223 paper. Only 10 of the chemicals are used exclusively in paper production (mainly biocides). 224 Conversely, 133 chemicals were attributed to the printing industry, most of which are solvents and 225 polymeric resins employed in inks, pigments and dyes. Chemicals which could not be attributed 226 either to paper production or to the printing sector (14) could potentially be by-products or 227 contaminants introduced into the production cycle through recycled paper.

228 Table 1. Data sources used in the study and their quantitative contribution to Step 1 list of 229 chemicals.

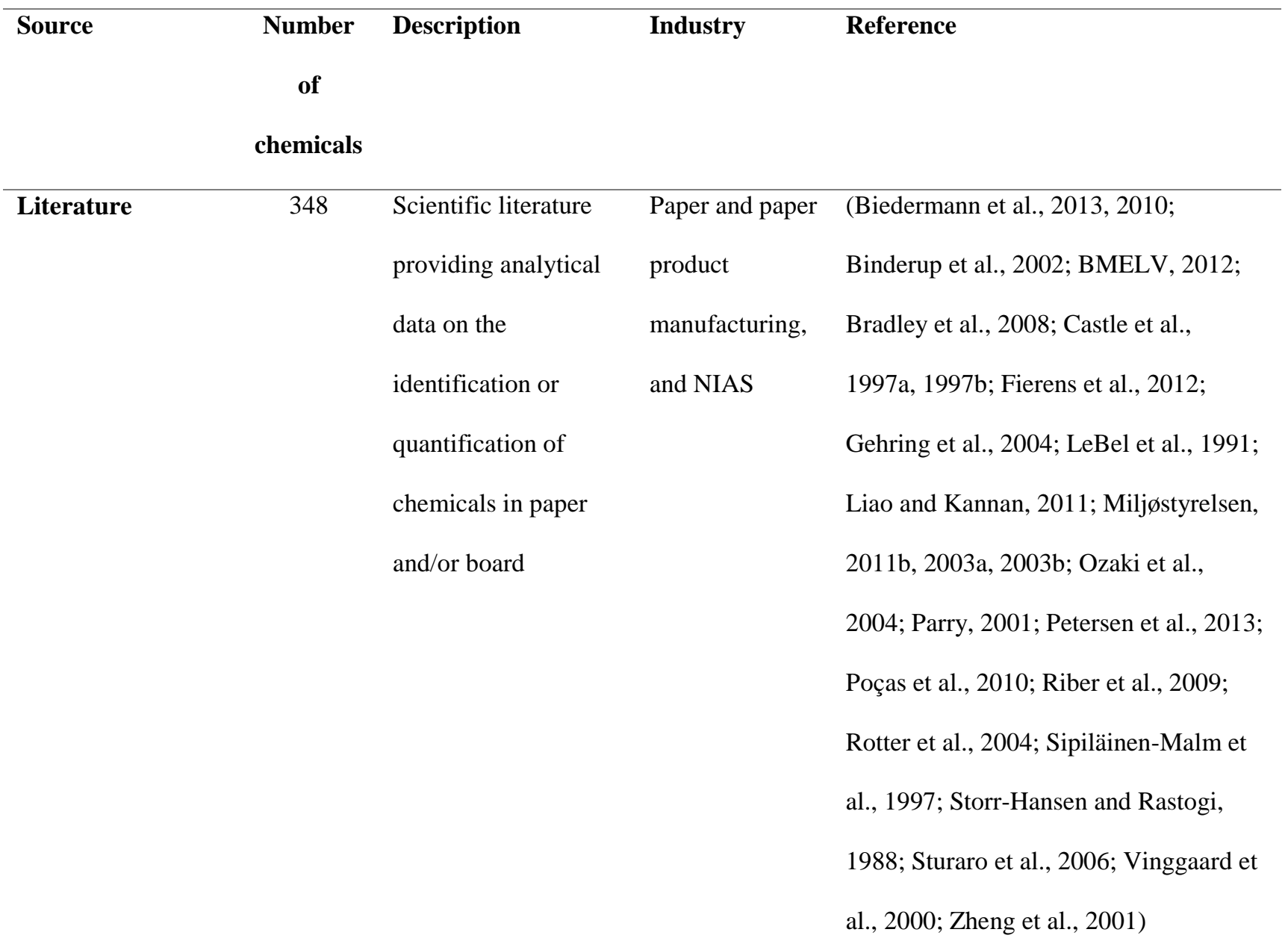




\begin{tabular}{|c|c|c|c|c|}
\hline $\begin{array}{l}\text { Danish product } \\
\text { register }\end{array}$ & 75 & $\begin{array}{l}\text { Chemicals used in } \\
\text { preparations of } \\
\text { articles. Danish } \\
\text { industry for pulp, } \\
\text { paper and paper } \\
\text { products }\end{array}$ & $\begin{array}{l}\text { Paper and paper } \\
\text { product } \\
\text { manufacturing }\end{array}$ & (SPIN, 2013) \\
\hline $\begin{array}{l}\text { Swedish product } \\
\text { register }\end{array}$ & 144 & $\begin{array}{l}\text { Chemicals used in } \\
\text { preparations of } \\
\text { articles. Swedish } \\
\text { industry for pulp, } \\
\text { paper and paper } \\
\text { products }\end{array}$ & $\begin{array}{l}\text { Paper and paper } \\
\text { product } \\
\text { manufacturing }\end{array}$ & (KEMI, 2014) \\
\hline $\begin{array}{l}\text { Danish } \\
\text { Environmental } \\
\text { Protection Agency }\end{array}$ & 415 & $\begin{array}{l}\text { Inventory of } \\
\text { chemicals used by the } \\
\text { Danish printing } \\
\text { industry }\end{array}$ & $\begin{array}{l}\text { Paper product } \\
\text { manufacturing* }\end{array}$ & (Miljøstyrelsen, 2011a) \\
\hline RiskCycle & 12 & $\begin{array}{l}\text { Database of chemical } \\
\text { additives used in } \\
\text { paper production }\end{array}$ & $\begin{array}{l}\text { Paper } \\
\text { manufacturing }\end{array}$ & (Riskcycle, 2013) \\
\hline ZELLCHEMING & 44 & $\begin{array}{l}\text { Chemical additives } \\
\text { for the production of } \\
\text { pulp and paper }\end{array}$ & $\begin{array}{l}\text { Paper } \\
\text { manufacturing }\end{array}$ & (ZELLCHEMING, 2008) \\
\hline EFSA & 223 & $\begin{array}{l}\text { Chemicals currently } \\
\text { used in the } \\
\text { manufacture of paper } \\
\text { and board }\end{array}$ & $\begin{array}{l}\text { Paper } \\
\text { manufacturing }\end{array}$ & (EFSA, 2012a) \\
\hline FDHA & 4575 & $\begin{array}{l}\text { Chemicals permitted } \\
\text { to be used in the } \\
\text { manufacture of }\end{array}$ & $\begin{array}{l}\text { Paper product } \\
\text { manufacturing* }\end{array}$ & (FDHA, 2005) \\
\hline
\end{tabular}




\begin{tabular}{llll}
\hline & packaging inks \\
\hline EuPIA & 3858 & Inventory list of & Paper product $\quad$ (EuPIA, 2012) \\
& chemicals used in the $\quad$ manufacturing* \\
& manufacture of food \\
& & packaging inks \\
& & & \\
& &
\end{tabular}

\section{TOTAL:}

9694

*not limited to paper matrix

Chemicals on the Step 2 list were assessed in relation to their potential partitioning between a higher affinity for a solid matrix (51) or remain dissolved in the water phase (51). Sixteen of the chemicals on the list are relatively volatile and could potentially escape through volatilisation in the production process, while an additional 22 substances on the list are inorganic, and although two of them (i.e. mercury and carbon disulphide) may partially volatilise, the distribution of the rest will depend very much on specific conditions in the paper processing stages (e.g. $\mathrm{pH}$, redox conditions, presence of organic matter, etc.) and are difficult to predict. Chemicals remaining in the solid matrix are of particular interest in terms of paper recycling.

In the following step (Step 4) the biodegradability of the previously identified chemicals was assessed. As presented in Figure 3c, most of the substances that showed affinity for the solid phase 242 were characterised as persistent (24), while the 27 remaining chemicals could be classified as 243 inherently (12) and readily biodegradable (15). 
a

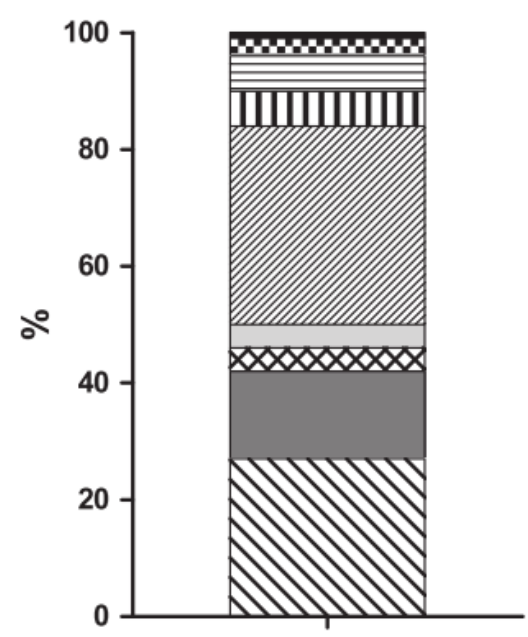

Function

Anti-foaming agents (2)

8 Binders (4)

$\sqsupseteq$ Biocides (9)

III By-product/contamination (10)

एun Other (54)

$\square$ Pigments (7)

$\otimes$ Plasticisers (6)

$\square$ Polymeric Resins (23)

$\Delta \nabla$ Solvents (42) b

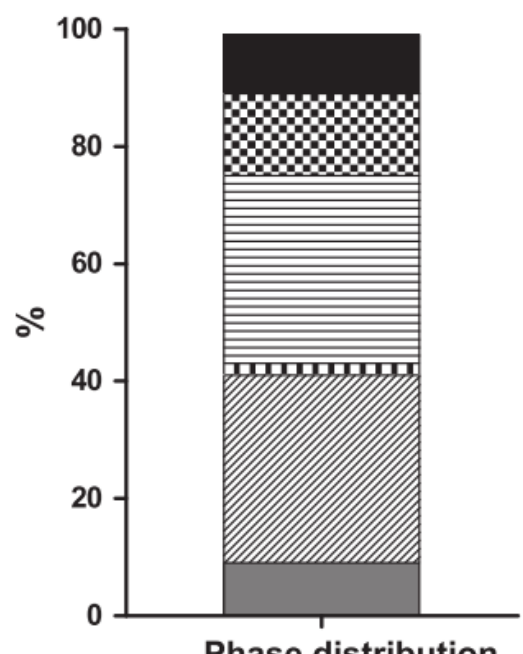

Phase distribution

Air (16)

$\$$ Inorganic (22)

Solid Phase (51)

WI Solid/Air (3)

שIs Water Phase (51)

$\square$ Water/Solid (14)

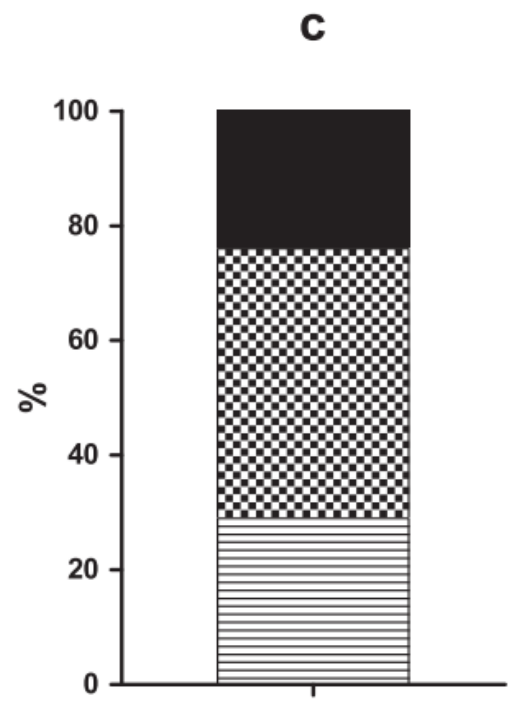

Biodegradability

- Inherently (12)

0 Persistent (24)

Readily (15)

245 Figure 3. Distribution of the use of chemicals from Step 2 list (3a); phase distribution of chemicals, 246 i.e. Step 3 list (3b); biodegradability of chemicals associated with the solid phase, i.e. Step 4 list 247 (3c).

While the list of potential priority chemical substances may not be exhaustive (as the

249 screening can only be based on available information about substances), it nevertheless clearly

250 indicates that concerns regarding their presence in paper and their potential accumulation in the

251 paper lifecycle may be pertinent to a relatively small number. The list therefore forms a systematic 252 basis for further research in relation to paper characteristics and paper recycling. The 157 253 substances identified in Step 2 are grouped in the following according to their chemical structure 
254 and then discussed in more detail. Individual tables listing each chemical substance according to 255 these groups can be found in the Supplementary Materials (Tables S1-S6).

\subsection{Mineral oils}

257 The commonly used term "mineral oils" refers to a mixture of components which originate from 258 crude oil refining processes. Mineral oils mainly contain straight and branched open-chain alkanes 259 (paraffins), alkylated cycloalkanes (naphthenes) and aromatic hydrocarbons (EFSA, 2012b), and 260 their final composition will depend largely on the initial composition of the crude oil, as well as the 261 refinery treatment (e.g. alkylation, hydro-treatment, cracking, extraction, etc.). Although the Joint FAO/WHO Expert Committee on Food Additives (JECFA) recently withdrew previously established acceptable daily intakes in relation to mineral oils (JECFA, 2012), the JECFA assessment refers to highly-refined mineral oils free from aromatic hydrocarbons. On the other 265 hand, paper products were shown to contain technical-grade mineral oils which may include aromatic hydrocarbons (Biedermann and Grob, 2010). Grob et al. (Droz and Grob, 1997) found that, at least initially, printing inks (solvents in particular) used in paper products are the main source of mineral oils in paper. Further studies have also posited that mineral oils may derive from recycled waste paper (Biedermann and Grob, 2010; Biedermann et al., 2011b).

Out of the 157 chemicals included in the Step 2 list, 49 were classified as mineral oils (Table S1 (Supplementary Material)) and characterised as carcinogens, while some are also mutagenic substances. The chemicals presented herein are not single substances but rather mixtures of substances containing various hydrocarbons. Being mixtures rather than single substances, mineral oils can be used in a variety of applications in the industry, i.e. from solvents and as the basis for 275 polymeric resins through to lubricants and cleaning agents for machinery (EFSA, 2012b; 276 Miljøstyrelsen, 2011a). Most of the scientific studies currently available focus on mineral oil content in paper used for food packaging (e.g. (Biedermann and Grob, 2010; Biedermann et al., 
2011a, 2011b; Droz and Grob, 1997)), as migration into foodstuffs remains one of the most important sources of consumer exposure (EFSA, 2012b). As they are hydrophobic substances, mineral oils may not be removed in water-based processes of paper recycling (i.e. pulping, deinking, washing), remain in the solid matrix and have a high chance of persisting in the recycling process and being reintroduced into newly manufactured products (BMELV, 2012). Such a scenario is unlikely for some of the lighter mineral oils, which are expected to escape due to volatilisation in e.g. paper drying step. A recent study (BMELV, 2012) showed that the deinking process reduces insignificantly the concentration of mineral oils, while paper drying is the main process for their removal (around 30\% (Biedermann et al., 2011b)) - still resulting on average in $340 \mathrm{mg} / \mathrm{kg}\left(<\mathrm{C}_{24}\right)$ in unprinted food-packaging board produced (Biedermann and Grob, 2012). One study showed that even the presence of a barrier (e.g. plastic foil) may not always prevent the migration of mineral oils from packaging into a food product (Fiselier and Grob, 2012), and a biodegradation assessment has shown that a significant number of mineral oils (15) can be classified as persistent, making bioaccumulation relevant for some.

Due to the diversity of mineral oils, and the fact that they are mixtures, identifying and quantifying single constituents (as the ones presented in Table S1 (Supplementary Material)) is practically impossible. As a result, mineral oils are analysed instead as sum parameters (e.g. the Hydrocarbon Oil Index), with fractioning based on the number of carbon atoms in the chemical (Droz and Grob, 1997; Pivnenko et al., 2013) or fractioning between mineral oil saturated and aromatic hydrocarbons (Biedermann and Grob, 2010; Biedermann et al., 2011b). The study conducted by Pivnenko et al. (2013) showed the presence of mineral oils in all the analysed waste paper fractions, with the highest concentrations (up to $1,800 \mathrm{mg} / \mathrm{kg}$ ) identified in newspapers and tissue paper. Similarly, among waste paper materials fed into the German recycling loop, newspapers were identified as the main source of mineral oils (BMELV, 2012). Their presence in 
newspapers can be attributed to solvents and processes used in cold off-set printing (Biedermann and Grob, 2010), while mineral oils in tissue paper may indicate the introduction of chemicals during the product's life span and waste management. Both studies mentioned above (BMELV, 2012; Pivnenko et al., 2013) present relatively stable concentrations of mineral oils in a variety of board products, potentially indicating a contribution made by newspaper recycling.

\subsection{Phthalates}

308 Most phthalates are used as plasticisers in the preparation of printing inks, lacquers and dispersion 309 glues (BfR, 2007; CDC, 2009), though they can also be used as softeners in tissue paper 310 (Miljøstyrelsen, 2003a). From the Step 2 list, seven phthalates were identified (Table S2 311 (Supplementary Material)), the majority of which are classified as EDCs, while reproductive 312 toxicity is also attributed to some. Phase distribution assessment (Step 3) revealed that phthalates 313 may be retained in the paper and pulp solid matrices and could potentially follow the production 314 process until the final product. Benzyl butyl phthalate (BBP), Dibutyl phthalate (DBP) and 315 Diethylhexyl phthalate (DEHP) are classified as persistent, according to the criteria used. Table S2 316 (Supplementary Material) reveals the range of concentrations of phthalates quantified in paper, with 317 Diisobutyl phthalate (DIBP) reaching the highest concentrations (up to $120 \mathrm{mg} / \mathrm{kg}$ ). A study 318 conducted by a German authority (BMELV, 2012) showed that phthalates were mainly present (up 319 to $35 \mathrm{mg} / \mathrm{kg}$ ) in board, waste paper from offices, specialty paper and papers containing relatively 320 high amounts of glue. In contrast, newspapers, magazines and advertisements contained almost one 321 order of magnitude lower phthalate concentrations (BMELV, 2012). These results could potentially 322 indicate adhesives as the main source of phthalates in paper for recycling.

Experimental results involving four separate recycling facilities producing board for food 324 packaging indicated that in the recycling process, phthalates have a high affinity for paper fibres, moving through the production line and then into final products (BMELV, 2012). Particularly, the 
study showed that DIBP, DBP and DEHP have a tendency (on average) to accumulate in board produced from recycled paper. On the other hand, the same study showed that virgin fibre-based board contained phthalates in lower concentrations $(<0.2 \mathrm{mg} / \mathrm{kg})$ well below one order of magnitude.

\subsection{Phenols}

331 Among the 157 chemicals in Step 2, eight were identified as phenols (Table S3 (Supplementary 332 Material)), all of which fulfilled the EDCs criteria. The use of phenols in the paper industry varies 333 significantly; for example, Bisphenol A (BPA) is used as a developer in thermal paper and pentachlorophenol as a biocide in paper production (Mendum et al., 2011; ZELLCHEMING, 2008).

Octylphenol, 4-nonylphenol and 4-tert-octylphenol are used in polymeric resins employed in ink preparation (EuPIA, 2012), while nonylphenol is part of some surfactants used in the printing (Miljøstyrelsen, 2011a). The majority of thermal paper is used in cash register receipts, which may contain up to 17,000 mg/kg of BPA (Miljøstyrelsen, 2011b). The remaining chemicals in Table S3 (Supplementary Material) show significantly lower concentration ranges (0.01-68.9 mg/kg) when compared to those of BPA $(0.068-17,000 \mathrm{mg} / \mathrm{kg})$.

Liao \& Kannan (2011) detected BPA in the majority of 99 paper products analysed, which included magazines, paper towels, napkins, flyers, printing papers, etc., thus indicating potential spreading due to recycling. Similarly, another study (BMELV, 2012) found the highest concentrations of BPA in board packaging which was assumed to have the highest content of recycled paper. Structural BPA analogues (e.g. BPB, BPS, BPF, etc.) are available on the market, but the potential health effects of substitutes are still to be assessed in detail (Rosenmai et al., 2013). Phenols deserve special attention in terms of paper recycling, as nearly all of them demonstrate a high affinity to solids and are persistent, according to biodegradability criteria. The removal of BPA in the deinking process has been observed to be higher than $50 \%$, but this still resulted in average 
concentrations of BPA of $10 \mathrm{mg} / \mathrm{kg}$ in the board produced (BMELV, 2012). This was in contrast to 351 board based on virgin fibres, where no BPA was detected.

\subsection{Parabens}

Esters of $p$-hydroxybenzoic acid, or parabens, are commonly used as preservatives in a variety of consumer products (Miljøstyrelsen, 2013). Butyl, ethyl, methyl and propyl parabens, identified in Step 2 (Table S4 (Supplementary Material)) and which may be used as preservatives and biocides by both the paper and the printing sectors (Miljøstyrelsen, 2011a; Vinggaard et al., 2000), are all classified as EDCs and show a tendency to remain in aqueous solution. Hence, they can be expected to be removed in the wet end of paper production. Only butyl and propyl parabens show a partial affinity to solids, which may constitute an issue in paper recycling. Although no limit values for chemicals in paper in Table S4 (Supplementary Material) were available, 'no release of substances in quantities which have an antimicrobial effect' applies to food-contact paper, in accordance with paper industry guidelines (CEPI, 2012). In a study investigating the oestrogenic potential of paper for household use, parabens (methyl and propyl paraben) were identified only in samples of paper made from virgin fibres (Vinggaard et al., 2000).

\subsection{Inorganics}

Out of the 157 chemicals, 22 substances were inorganic (Table S5 (Supplementary Material)). Inorganic chemicals in general, and potentially toxic metals in particular, are used mostly in pigment preparation and coatings (Miljøstyrelsen, 2011a). The presence of $\mathrm{Hg}$ could not be attributed to any particular process, and it was therefore assumed to be the result of impurities and/or contamination (Huber, 1997). Nevertheless, two studies addressing waste paper composition found $\mathrm{Hg}$ in measurable concentrations (Riber et al., 2009; Rotter et al., 2004). Most of the chemicals presented in Table S5 (Supplementary Material) have not been reported based on 
analytical experiments but rather from inventory lists indicating their use by industry. 374 Concentrations of $\mathrm{Hg}$ ranged from 0.01 to $0.386 \mathrm{mg} / \mathrm{kg}$, Cd ranged from 0.02 to $0.3 \mathrm{mg} / \mathrm{kg}$, while total $\mathrm{Cr}$ was found in the highest concentrations at between 1.1 and $92 \mathrm{mg} / \mathrm{kg}$ of paper. Since some pigments and dyes may contain $\mathrm{Pb}$, one study showed that journals and magazines contained the highest concentrations (up to $400 \mathrm{mg} / \mathrm{kg}$ ) of $\mathrm{Pb}$ in recyclable waste paper (BMELV, 2012). The same study also mentioned that the levels of $\mathrm{Hg}$ and $\mathrm{Cd}$ found were negligible. The limit values for $\mathrm{Cd}, \mathrm{Pb}$ and $\mathrm{Hg}$ in paper and board intended for use in food packaging were set at 0.5, 3.0 and 0.3 $\mathrm{mg} / \mathrm{kg}$, respectively (CEPI, 2012).

Due to the nature of inorganic constituents in waste paper, their removal in the recycling process may vary. One relevant study (BMELV, 2012) indicated that newly produced paper products based on recycled paper may still contain considerable concentrations of $\mathrm{Pb}$ (up to 26 $\mathrm{mg} / \mathrm{kg}$ ), while concentrations of some metals (Sn, Sb) may even increase during paper recycling, potentially indicating release from machinery (BMELV, 2012). Nevertheless, the authors of the study indicated that the presence of potentially toxic metals in the concentrations measured should not pose health hazards, even if the paper is to be used for food packaging.

\subsection{Other substances}

The remaining substances not falling within the previous groups amounted to 67 out of the original 157 (Table S6 (Supplementary Material)). Although data on their identification in paper are scarce, several of the chemicals have been quantified in the scientific literature and reports (BMELV, 2012; Ozaki et al., 2004; Storr-Hansen and Rastogi, 1988; Zheng et al., 2001). Polychlorinated biphenyls (PCBs) are classified as "Persistent Organic Pollutants" and are no longer used in paper production (e.g. in the carbonless copy paper), as they were abolished in 1993 (Breivik et al., 2007). Nevertheless, PCBs may persist in the environment, for example accumulated in trees (Hermanson and Johnson, 2007) or other sources (e.g. books and archives), and they may therefore be 
introduced into the paper production process. Diisopropyl naphthalene (DIPN) substitutes for PCBs in carbonless copy paper and may be used in other applications (Biedermann and Grob, 2012). It was shown that among the waste paper analysed, office paper contained the highest concentrations of DIPN (up to $1,400 \mathrm{mg} / \mathrm{kg}$ ), indicating that specialty paper and the use of recycled paper are 401 important sources thereof (BMELV, 2012). The study also showed that unconverted board made 402 from recycled paper and intended for food packaging may contain DIPN ranging from 11 to 27 403 $\mathrm{mg} / \mathrm{kg}$. chlorine in the paper bleaching process have lowered the possibility of dioxin and furan formation (Ginebreda et al., 2012), these substances may still be detectable in paper products and other papermill outputs, albeit at very low levels (Latorre et al., 2005). The presence of dioxins and furans estimated in papermill effluent waters was in the range of approximately $1-10 \mathrm{ng} / \mathrm{m}^{3}$ (Latorre et al., 2005), while Munawar et al. identified both in lake sediments near pulp and papermill facilities (Munawar et al., 2000). Another study showed waste paper as the main source of dioxins and furans in a paper recycling facility (Santl et al., 1994). The issue is especially relevant for emerging economies, where potentially more lenient environmental legislations are applied and elemental 413 chlorine may still be in use, thus resulting in detectable levels of dioxins and furans in pulp, paper 414 and effluents (Thacker et al., 2007; Zheng et al., 2001).

The attention of the paper industry to some of the chemicals listed in Table S6 416 (Supplementary Material) has already been drawn, leading to setting limit concentration values for 417 paper and board used in food packaging: DIPN is subject to tests only in products containing 418 recycled paper, and these concentrations should be 'as low as technically possible' (CEPI, 2012). 419 The same guidelines set the limit concentration of Mechler's ketone as low as $0.0016 \mathrm{mg} / \mathrm{dm}^{2}$. 
421 Although a relatively small number of substances were identified as critical (157 out of 422 approximately 10,000), there is a need for more information on their presence in waste paper 423 intended for recycling. Quantitative information on the presence of these substances could provide a 424 basis for establishing a priority list of chemicals to be monitored in waste paper prior to recycling as 425 well as in the final paper products. Although the paper industry has already placed focus on a range 426 of substances (e.g. BPA, BBP), the analytical methods needed to monitor others (e.g. substances 427 constituting mineral oils) are not readily available and represent a challenge for future research. 428 While the specific conditions of the paper recycling processes (i.e. temperature, $\mathrm{pH}$, residence time, 429 etc.) may influence the distribution of chemical substances between the solid, air, and liquid phases, 430 more analyses are needed to fully document substance distributions.

431 A general lack of transparency related to the use of specific chemicals for example in the 432 printing industry contributes with uncertainty about the substance load associated with paper 433 products and thereby also with the subsequent quality of waste paper as a resource for recycling. 434 Many of the substances screened in this study could not exclusively be associated with paper 435 printing; however, the substances could not be excluded either based on available information.

436 While banning or gradual phasing out of critical substances in paper production may in the 437 future lead to less chemical substances in paper for recycling, increased source-segregation of 438 individual paper types may also be necessary to ensure a high quality of the paper actually collected 439 for recycling. The preliminary results also indicate the necessity of addressing material quality 440 when establishing target recycling rates. Too high levels of critical substances in waste paper may 441 ultimately mean that this paper should be routed to thermal treatment, thereby enabling the 442 destruction of persistent organic chemicals.

\section{Conclusions}


444 The literature review clearly demonstrated that paper and board products, as well as waste paper, 445 may potentially contain a large number of chemical substances, many of these associated with the 446 printing industry. From a total list of 10,000 identified chemicals potentially present in paper 447 products, 157 were classified as hazardous. Fifty-one of these substances were identified as critical 448 as they were likely to remain in the solid matrix during paper recycling and thereby end up in new 449 products based on recycled fibres. The analytical literature reviewed indicated presence of several 450 substances (e.g. phthalates, phenols) in higher concentrations in recycled paper when compared to 451 virgin-fibre based products. If such recycled paper products include food packaging, migration into 452 foodstuff is potentially possible. As almost half of these chemicals (24) are classified as persistent 453 and potentially bio-accumulating, this may pose a risk for consumers. Most of the 51 chemicals are 454 intentionally added during manufacturing, while some of the substances (5) could not be attributed to any of the sectors within the paper industry. These substances may either be added unknowingly by the industry, or originate from contamination of the paper during the use phase or during collection and handling in the waste management phase. The study clearly demonstrates that there

458 is a need for more comprehensive quantitative data documenting the levels of potentially hazard 459 substances in paper sent to recycling as well as the final paper products. Based on the hazard 460 screening procedure, 51 substances have been identified as potentially critical. It is recommended 461 that analytical efforts are directed towards these substances.

\section{Acknowledgements}

463 The authors wish to thank the Confederation of European Paper Industries (CEPI) for facilitating 464 the data collection and providing constructive comments. Veronica Martinez Sanchez and Dr. 465 Alessio Boldrin (DTU Environment) are gratefully acknowledged for commenting on the 466 manuscript and engaging in constructive discussions. The Danish Research Council is acknowledge 467 for financial support through the 3R Research School and the IRMAR project. 
Baun, A., Eriksson, E., Ledin, A., Mikkelsen, P.S., 2006. A methodology for ranking and hazard identification of xenobiotic organic compounds in urban stormwater. Sci. Total Environ. 370, 29-38. doi:10.1016/j.scitotenv.2006.05.017

Becerra, V., Odermatt, J., 2012. Detection and quantification of traces of bisphenol A and bisphenol $S$ in paper samples using analytical pyrolysis-GC/MS. Analyst 137, 2250-9. doi:10.1039/c2an15961a

Begley, T.H., Hsu, W., Noonan, G., Diachenko, G., 2008. Migration of fluorochemical paper additives from food-contact paper into foods and food simulants. Food Addit. Contam. Part A. Chem. Anal. Control. Expo. Risk Assess. 25, 384-90. doi:10.1080/02652030701513784

BfR, 2007. Di-isobutylphthalate in food-contact paper and board, Working group "Paper and board”, Federal Institute for Risk Assessment. http://www.bfr.bund.de/cm/349/di_isobutyphthalate_in_food_contact_paper_and_board.pdf (accessed Feb 2014)

Biedermann, M., Grob, K., 2010. Is recycled newspaper suitable for food contact materials? Technical grade mineral oils from printing inks. Eur. Food Res. Technol. 230, 785-796. doi:10.1007/s00217-010-1223-9

Biedermann, M., Grob, K., 2012. On-line coupled high performance liquid chromatography-gas chromatography for the analysis of contamination by mineral oil. Part 2: migration from paperboard into dry foods: interpretation of chromatograms. J. Chromatogr. A 1255, 76-99. doi:10.1016/j.chroma.2012.05.096

Biedermann, M., Ingenhoff, J.-E., Barbanera, M., Garbini, D., Grob, K., 2011a. Migration of Mineral Oil into Noodles from Recycled Fibres in the Paperboard Box and the Corrugated Board Transport Box as well as from Printing Inks: A Case Study. Packag. Technol. Sci. 24, 281-290. doi:10.1002/pts.937

Biedermann, M., Ingenhoff, J.-E., Zurfluh, M., Richter, L., Simat, T., Harling, A., Altkofer, W., Helling, R., Grob, K., 2013. Migration of mineral oil, photoinitiators and plasticisers from recycled paperboard into dry foods: a study under controlled conditions. Food Addit. Contam. Part A. Chem. Anal. Control. Expo. Risk Assess. 30, 885-98.

Biedermann, M., Uematsu, Y., Grob, K., 2011b. Mineral oil contents in paper and board recycled to paperboard for food packaging. Packag. Technol. Sci. 24, 61-73. doi:10.1002/pts.914

Biedermann, S., Tschudin, P., Grob, K., 2010. Transfer of bisphenol A from thermal printer paper to the skin. Anal. Bioanal. Chem. 398, 571-6.

Binderup, M.L., Pedersen, G.A., Vinggaard, A.M., Rasmussen, E.S., Rosenquist, H., Cederberg, T., 2002. Toxicity testing and chemical analyses of recycled fibre-based paper for food contact. Food Addit. Contam. 19 Suppl, 13-28. 
BMELV, 2012. Ausmaß der Migration unerwünschter Stoffe aus Verpackungsmaterialien aus Altpapier in Lebensmitteln, BMELV (German Federal Ministry of Food, Agriculture and Consumer Protection). http://download.ble.de/09HS012.pdf (accessed Jan 14).

Bradley, E.L., Honkalampi-Hämäläinen, U., Weber, A., Andersson, M.A., Bertaud, F., Castle, L., Dahlman, O., Hakulinen, P., Hoornstra, D., Lhuguenot, J.-C., Mäki-Paakkanen, J., SalkinojaSalonen, M., Speck, D.R., Severin, I., Stammati, A., Turco, L., Zucco, F., von Wright, A., 2008. The BIOSAFEPAPER project for in vitro toxicity assessments: preparation, detailed chemical characterisation and testing of extracts from paper and board samples. Food Chem. Toxicol. 46, 2498-509.

Breivik, K., Sweetman, A., Pacyna, J.M., Jones, K.C., 2007. Towards a global historical emission inventory for selected PCB congeners--a mass balance approach 2. Emissions. Sci. Total Environ. 377, 296-307. doi:10.1016/j.scitotenv.2007.02.026

Castle, L., Damant, A.P., Honeybone, C.A., Johns, S.M., Jickells, S.M., Sharman, M., Gilbert, J., 1997a. Migration studies from paper and board food packaging materials. Part 2. Survey for residues of dialkylamino benzophenone UV-cure ink photoinitiators. Food Addit. Contam. 14, $45-52$.

Castle, L., Offen, C.P., Baxter, M.J., Gilbert, J., 1997b. Migration studies from paper and board food packaging materials. 1. Compositional analysis. Food Addit. Contam. 14, 35-44.

CDC, 2009. Fourth national report on human exposure to environmental chemicals, Department of Health and Human Services, Centers for Disease Control and Prevention, Atlanta GA, USA.

CEPI, 2012. Industry Guideline for the Compliance of Paper \& Board Materials and Articles for Food Contact, Confederation of European Paper Industries, Brussels, Belgium.

CEPI, 2013a. Key Statistics. European Pulp and Paper Industry 2012, Confederation of European Paper Industries, Brussels, Belgium.

CEPI, 2013b. CEPI sustainability report 2013. European Paper Industry - Advancing the bioeconomy, Confederation of European Paper Industries, Brussels, Belgium.

Droz, C., Grob, K., 1997. Determination of food contamination by mineral oil material from printed cardboard using on-line coupled LC-GC-FID. Zeitschrift für Leb. und -forsch. A 239-241.

EC, 2004. European Commission (EC), Regulation No 1935/2004 of the European Parliament and of the Council of 27 October 2004 on materials and articles intended to come into contact with food and repealing Directives 80/590/EEC and 89/109/EEC. Off J Eur Union L338: 4-17.

EC, 2006. European Commission (EC), Regulation No 1907/2006 of the European Parliament and the Council of 18 December 2006 concerning the Registration, Evaluation, Authorisation and Restriction of Chemicals (REACH), establishing a European Chemicals Agency, amending Directive 1999/45/EC and. Off J Eur Union L396: 1-849. 
EC, 2008. European Commission (EC), Regulation No 1272/2008 of the European Parliament and of the Council of 16 December 2008 on classification, labelling and packaging of substances and mixtures, amending and repealing Directives 67/548/EEC and 1999/45/EC, and amending Regulation (EC) No 1. Off J Eur Union L353: 1-1355.

EFSA, 2012a. Report of ESCO WG on non-plastic Food Contact Materials, European Food Safety Authority (EFSA), Parma, Italy 1-63.

EFSA, 2012b. Scientific Opinion on Mineral Oil Hydrocarbons in Food. EFSA J. 10(6), 27042889.

EuPIA, 2012. Inventory list - version June 2012. Comprising of packaging ink raw materials applied to the non-food contact surface of food packaging. European Printing Ink Association. Brussels, Belgium.

EuPIA, 2013. Annual report. European Printing Ink Association. http://www.eupia.org/uploads/tx_edm/EuPIA_Annual_Report_2013.pdf (accessed Mar 2014).

FDHA, 2005. Ordinance of the FDHA on Materials and Articles RS 817.023.21, Swiss Federal Department of Home Affairs (FDHA).

FEICA, 2008. Adhesives and sealants demand in Europe in 2008. Market statistics. European Adhesives and Sealant Industry. http://www.feica.com/ feica/index.php?option=com_content\&view=article\&id=28\&Itemid=5 2 (accessed Mar 2014).

Fierens, T., Servaes, K., Van Holderbeke, M., Geerts, L., De Henauw, S., Sioen, I., Vanermen, G., 2012. Analysis of phthalates in food products and packaging materials sold on the Belgian market. Food Chem. Toxicol. 50, 2575-2583.

Fiselier, K., Grob, K., 2012. Barriers against the Migration of Mineral Oil from Paperboard Food Packaging: Experimental Determination of Breakthrough Periods. Packag. Technol. Sci. 25, 285-301. doi:10.1002/pts.982

Gärtner, S., Balski, M., Koch, M., Nehls, I., 2009. Analysis and migration of phthalates in infant food packed in recycled paperboard. J. Agric. Food Chem. 57, 10675-81. doi:10.1021/jf902683m

Geens, T., Goeyens, L., Kannan, K., Neels, H., Covaci, A., 2012. Levels of bisphenol-A in thermal paper receipts from Belgium and estimation of human exposure. Sci. Total Environ. 435-436, 30-3. doi:10.1016/j.scitotenv.2012.07.001

Gehring, M., Tennhardt, L., Vogel, D., 2004. Bisphenol A contamination of wastepaper, cellulose and recycled paper products, in: Brebbia, C.A., Kungolos, S., Popov, V., Itoh, H. (Eds.), Waste Management and the Environment II. WIT Press, pp. 293-301.

Ginebreda, A., Guillén, D., Barceló, D., Darbra, R., 2012. Additives in the Paper Industry, in: Bilitewski, B., Darbra, R.M., Barceló, D. (Eds.), Global Risk-Based Management of Chemical 
Additives I SE - 109, The Handbook of Environmental Chemistry. Springer Berlin Heidelberg, pp. 11-34. doi:10.1007/698_2011_109

Hermanson, M.H., Johnson, G.W., 2007. Polychlorinated biphenyls in tree bark near a former manufacturing plant in Anniston, Alabama. Chemosphere 68, 191-198.

Huber, K., 1997. Wisconsin Mercury SourceBook, Wisconsin Department of Natural Resources, Madison, Wisconsin, USA. http://infohouse.p2ric.org/ref/04/03851.htm (accessed May 2014).

ITC, 2014. International trade in goods - Imports 2001-2013. International Trade Center. http://www.intracen.org/itc/market-info-tools/statistics-import-product-country/ (accessed Mar 2014).

JECFA, 2012. Joint FAO/WHO Expert Committee on Food Addittives, Seventy-sixth meeting, Geneva, Switzerland. http://www.fao.org/fileadmin/user_upload/agns/pdf/76th_JECFA_summary_report.pdf (accessed Oct 2014).

KEMI, 2014. Overview of chemicals, Swedish Chemicals Agency http://kemi.se/en/Content/Statistics/Overview-of-chemicals/ (accessed Mar 2014).

Latorre, A., Rigol, A., Lacorte, S., Barcelo, D., 2005. Organic compounds in paper mill wastewaters, in: Barceló, D. (Ed.), The Handbook of Environmental Chemistry, The Handbook of Environmental Chemistry. Springer-Verlag, Berlin/Heidelberg, pp. 25-51. doi:10.1007/b97783

Laurijssen, J., Marsidi, M., Westenbroek, A., Worrell, E., Faaij, A., 2010. Paper and biomass for energy? Resour. Conserv. Recycl. 54, 1208-1218. doi:10.1016/j.resconrec.2010.03.016

LeBel, G.L., Williams, D.T., Benoit, F.M., 1991. Determination of chlorinated dibenzodioxins and dibenzofurans in selected paper products. Chemosphere 23, 737-746.

Liao, C., Kannan, K., 2011. Widespread occurrence of bisphenol A in paper and paper products: implications for human exposure. Environ. Sci. Technol. 45, 9372-9.

Lorenzini, R., Biedermann, M., Grob, K., Garbini, D., Barbanera, M., Braschi, I., 2013. Migration kinetics of mineral oil hydrocarbons from recycled paperboard to dry food: monitoring of two real cases. Food Addit. Contam. Part A. Chem. Anal. Control. Expo. Risk Assess. 30, 760-70. doi:10.1080/19440049.2013.766765

Mendum, T., Stoler, E., VanBenschoten, H., Warner, J.C., 2011. Concentration of bisphenol A in thermal paper. Green Chem. Lett. Rev. 4, 81-86. doi:10.1080/17518253.2010.502908

Miljøstyrelsen, 2003a. Survey of chemical substances in paper handkerchiefs and toilet paper. Survey of chemical substances in consumer products No. 34, Miljøstyrelsen (Danish EPA), Copenhagen, Denmark. 
Miljøstyrelsen, 2003b. Survey, emission and evaluation of volatile organic chemicals in printed matter. Survey of chemical compounds in consumer products No. 36, Miljøstyrelsen (Danish EPA), Copenhagen, Denmark.

Miljøstyrelsen, 2011a. Kemikaliesubstitution i grafisk branche, Miljøproject Nr. 1354, Miljøstyrelsen (Danish EPA), Copenhagen, Denmark.

Miljøstyrelsen, 2011b. Migration of bisphenol A from cash register receipts and baby dummies. Survey of chemical substances in consumer products No. 110, Miljøstyrelsen (Danish EPA) , Copenhagen, Denmark.

Miljøstyrelsen, 2013. Survey of parabens. Environmental project No. 1474, Miljøstyrelsen (Danish EPA), Copenhagen, Denmark.

Moench, D., Auhorn, W., 2002. Chemical additives for papermaking - Products, trends, industry consolidation, in: Annual Meeting; 88th, Pulp and Paper Technical Association of Canada. pp. 109-112.

Munawar, M., Munawar, I.F., Sergeant, D., Wenghofer, C., 2000. A preliminary bioassessment of Lake Baikal sediment toxicity in the vicinity of a pulp and paper mill. Aquat. Ecosyst. Health Manag. 3, 249-257. doi:10.1080/14634980008657023

Ozaki, A., Yamaguchi, Y., Fujita, T., Kuroda, K., Endo, G., 2004. Chemical analysis and genotoxicological safety assessment of paper and paperboard used for food packaging. Food Chem. Toxicol. 42, 1323-37.

Parry, S., 2001. Neutron activation analysis of recycled paper and board in contact with food. J. Radioanal. Nucl. Chem. 248, 143-147.

Petersen, J.H., Jensen, L.K., Jespersen, H.T., Sørensen, F., Schaumburg, K., 2013. Fødevareemballager af trykt papir og pap. Udvikling og validering af analysekoncept, DTU Fødevareinstituttet (Danish National Food Institute), Søborg, Denmark.

Pivnenko, K., Eriksson, E., Astrup, T.F., 2013. Presence of potentially critical substances in waste paper, in: R. Cossu, P. He, P. Kjeldsen, Y. Matsufuji, D. Reinhart, R. Stegmann (Eds.), Proceedings of the Fourteenth Waste Management and Landfill Symposium, Sardinia 2013, S.Margherita di Pula. Proc. Sardinia 2013.

Poças, M.F., Oliveira, J.C., Pereira, J.R., Hogg, T., 2010. Consumer exposure to phthalates from paper packaging: an integrated approach. Food Addit. Contam. Part A. Chem. Anal. Control. Expo. Risk Assess. 27, 1451-9.

Riber, C., Petersen, C., Christensen, T.H., 2009. Chemical composition of material fractions in Danish household waste. Waste Manag. 29, 1251-7.

Riskcycle, 2013. Risk-based management of chemicals and products in a circular economy at a global scale, Chemical Additive Database. http//www.riskcycle.es (accessed Nov 2013). 
Rosenmai, A., Dybdahl, M., Pedersen, G.A., Pedersen, M., van Vugt-Lussenburg, B., Taxvig, C., Vinggard, A.M., 2013. Are structural analogues to bisphenol A a safe alternative? Toxicol. Lett. 221.

Rotter, V.S., Kost, T., Winkler, J., Bilitewski, B., 2004. Material flow analysis of RDF-production processes. Waste Manag. 24, 1005-21.

Santl, H., Bichlmaier, A., Gruber, L., Stöhrer, E., 1994. Mass balance of polychlorinated dibenzofurans (PCDFs) and polychlorinated dibenzodioxins (PCDDs) in a recycling paper mill. Chemosphere 28, 1633-1639.

Sipiläinen-Malm, T., Latva-Kala, K., Tikkanen, L., Suihko, M.L., Skyttä, E., 1997. Purity of recycled fibre-based materials. Food Addit. Contam. 14, 695-703.

Song, Y.S., Park, H.J., Komolprasert, V., 2000. Analytical Procedure for Quantifying Five Compounds Suspected as Possible Contaminants in Recycled Paper/Paperboard for Food Packaging. J. Agric. Food Chem. 48, 5856-5859. doi:10.1021/jf000512x

SPIN, 2013. Substances in Preparations in Nordic countries (SPIN). http//195.215.202.233/DotNetNuke/default.aspx (accessed Oct 2013).

Storr-Hansen, E., Rastogi, S.C., 1988. Polychlorinated biphenyls and heavy metal levels in recycled paper for household use. Bull. Environ. Contam. Toxicol. 40, 451-456.

Sturaro, A., Rella, R., Parvoli, G., Ferrara, D., Tisato, F., 2006. Contamination of dry foods with trimethyldiphenylmethanes by migration from recycled paper and board packaging. Food Addit. Contam. 23, 431-6. doi:10.1080/02652030500526052

Thacker, N.P., Nitnaware, V.C., Das, S.K., Devotta, S., 2007. Dioxin formation in pulp and paper mills of India. Environ. Sci. Pollut. Res. - Int. 14, 225-226. doi:10.1065/espr2007.02.386

Trier, X., Granby, K., Christensen, J.H., 2011. Polyfluorinated surfactants (PFS) in paper and board coatings for food packaging. Environ. Sci. Pollut. Res. Int. 18, 1108-20. doi:10.1007/s11356010-0439-3

U.S. EPA, 2013. Estimation Program Interface (EPI) Suite, v4.1, United States Environ. Prot. Agency, Washington, DC, USA. http://www.epa.gov/oppt/exposure/pubs/episuite.htm (accessed Feb 2014).

Villanueva, A., Wenzel, H., 2007. Paper waste - recycling, incineration or landfilling? A review of existing life cycle assessments. Waste Manag. 27, S29-46. doi:10.1016/j.wasman.2007.02.019

Vinggaard, A.M., Körner, W., Lund, K.H., Bolz, U., Petersen, J.H., 2000. Identification and Quantification of Estrogenic Compounds in Recycled and Virgin Paper for Household Use As Determined by an in Vitro Yeast Estrogen Screen and Chemical Analysis. Chem. Res. Toxicol. 13, 1214-1222. 
678 WHO, 2002. Global assessment of the state-of-the-science of endocrine disruptors, World Health $679 \quad$ Organization.

680 ZELLCHEMING, 2008. Chemical Additives for the Production of Pulp \& Paper, Ed. by 681 ZELLCHEMING Technical Committee "Chemical Additives (CHAD)”, Deutscher Fachverlag 682 Publisher.

683 Zheng, M.-H., Bao, Z.-C., Zhang, B., Xu, X.-B., 2001. Polychlorinated dibenzo-p-dioxins and 684 dibenzofurans in paper making from a pulp mill in China. Chemosphere 44, 1335-1337.

685 